\title{
105 ものつくりオフィスアワーを通した技術者教育の取り組み
}

\section{An Attempt of Engineering Education through Office Hours for Manufacturing} ○ 正 小林 義和（秋田高専） 西野智路（秋田高専）

Yoshikazu KOBAYASHI, Akita National College of Technology,1-1 lijima,Bunkyocho,Akita City Tomomichi NISHINO, Akita National College of Technology

Key Words: manufacturing skill, introductory manufacturing education, Monodukuri office hours

\section{1. 精耳}

学生のものづくりスキルを向上させる目的から秋田高 専では 2006 年より全学科の 1 年生を対象にものづくり導 入教育を実施している。導入教育を受講した 1 年生と 2 年 生を対象としたアンケートの結果によれば，約 50\%以上の 学生がものづくり教育は彼らの専門に有用であり，また将 来自分自身でものづくりをやってみたいと答えていること が分かった. しかしながら 2 年生の学生の約半数がものづ くりに対する興味を失っているという結果を得た。そこで, 主に 2 年生以上の学生を対象として放課後の課外活動の時 間を利用してものづくりオフィスアワーといら取り組みを 行ったところ, 徐々に学生のものづくりに対する興味が向 上する結果を得たので報告する.

\section{2.ものづくり毞入教育}

秋田高専では， 1 学年の全学科（機械工学科, 電気情報 工学科, 物質工学科, 環境都市工学科) でものぶくり導入 教育を実施している. 具体的な授業内容としては，安全教 育およびガイダンスの後，コマの製作（旋盤），ペンホルダ 一の製作 (フライス盤)，写真立ての製作（手仕上げ），小 箱の製作（板金作業）の 4 つの作業を実施している。も づくり導入教育は実習工場と工業技術実習センターで行わ れている. 授業スタッフは 4 名の技術専門職員と各学科か ら選出された 1 名の教員から構成されている. 図 1 は実習 工場での工作実習の様子を示している.

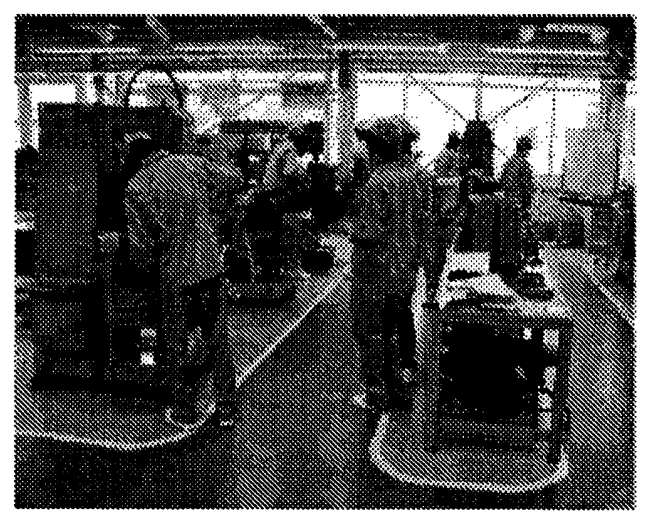

Fig. 1 Manufacturing processes in workshop

\section{3.ものつくり算入教育に関するアンケート调查}

2009 年 9 月に,ものづくり導入教育を受講した 1 年生 と 2 年生を対象にアンケート調查を実施した. 図 2 図 4 に得られた結果の一部を示す。な打図中 $1 \mathrm{M}, 1 \mathrm{C}, 1 \mathrm{~B}, 2 \mathrm{E}, 2 \mathrm{C}, 2 \mathrm{~B}$ の 1 は 1 年生, 2 は 2 年生の結果を, また $\mathrm{M}, \mathrm{E}, \mathrm{C}, \mathrm{B}$ はそれぞれ機械工学科，電気情報工学科，物 質工学科, 環境都市工学科を示す.

結果を要約すると次のようである。ものづくり教育が専 門科目に役立つかについて聞いた図 2（問 1 ）では， 1 年 生の $70 \%$ 95\%が役立つと考えているが， 2 年生になると

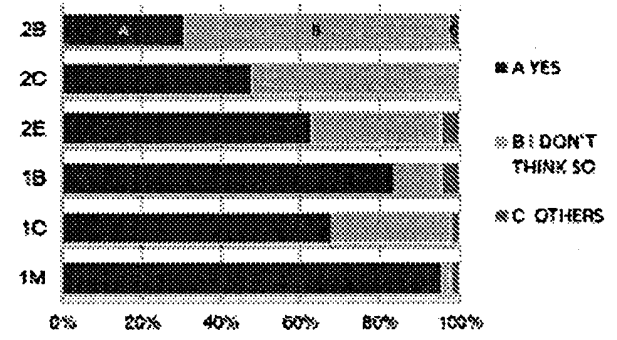

Question 1: Do you think that the contents of manufacturing education are useful for your specialty?

Fig. 2 Relation between manufacturing education and each department specialty

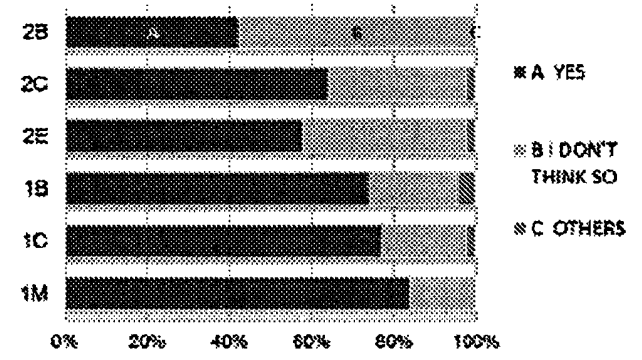

Question 2: Do you want to manufacture in your own in future through the experience gained in class?

Fig. 3 Interest in manufacturing 


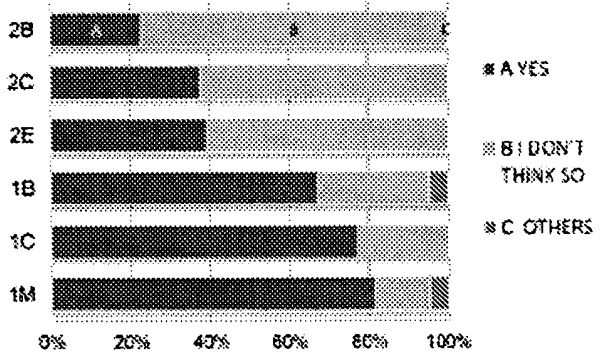

Question 3: Do you hope that there is manufacturing education above second grade?

Fig. 4 Manufacturing education for above second grade

トータルで 50\%程度まで減少することが分かった．

図 3 および 4 （問 2 , 問 3 ）より，75\%以上の 1 年生が 自分自身でものづくりをしてみたいと答えていて，また約 $70 \%$ の 1 年生が 2 年生以上でもものづくりをしてみたいと 思っていることが分かった。 しかしながら， 2 年生になる と興味の割合が減少している。この理由として，2 年生に なると，ものづくり実習の科目がなくなり，専門の科目が 増え興味が専門科目に向かってしまうことが考えられる. そのため, 特に 2 年生以上の学生のものづくりに対する興 味を改善するために，水曜日の放課後 5 時〜 6 時に「もの づくりオフィスアワー」と称する取り組みを始めることと した.

\section{4.ものづくりオフィスアワー}

ものづくりオフィスアワーは実習工場と併設されてい る工業技術実習センターで実施されている，スタッフは， 各学科から選出された高専ロボコンの指導教員が当たって いる. 各学科の教員が担当しているので，ものづくりが苦 手な学生でも工業実習センターに親しんでもらえると考え ている．ものづくりオフィスアワーでは旋盤やフライス盤 など工作機械を使用する作業だけでなく，自転車の修理や パソコンの修理など先に述べたものづくり導入教育の授業 内では扱うのが難しい内容についても取り扱っている．教 員はあくまでもアドバイスをしたり，道具の使い方を指導 し，場所を提供するだけで，必要な材料等は学生が準備す るといったスタンスで実施している．表 1 に示すように， 通学用自転車の整備・修理に利用している学生が多いこと が分かる.

ものづくりオフィスアワーの実例として，図 $5(\mathrm{a}),(\mathrm{b})$ ではノートP Cのバックライトを修理する学生, 自転車の パンク修理をする学生の作業風景を示す，実際に本取り組 みを継続した結果, 表 1 に示すように 2 年間で 34 例と決 して多いとはいえないが，これまでどちらかといえばもの

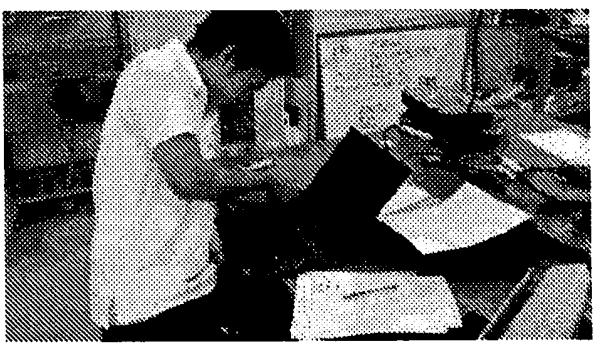

(a)

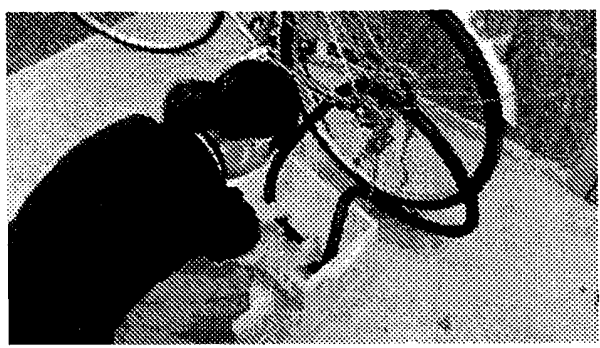

(b)

(a) Repairing the back-light of a notebook $\mathrm{PC}$

(b) Puncture repair of a bicycle

Fig. 5 Appearance of office hours for manufacturing

Table 1 Actual use result of Monodukuri office hours (Apr. 2010-Mar. 2012)

\begin{tabular}{l|c}
\hline Contents of consultation & number \\
\hline Repair of a personal computer & 4 \\
Repair of a bicycle & 13 \\
Puncture repair of a bicycle & 13 \\
Others & 4 \\
\hline Total & 34 \\
\hline
\end{tabular}

づくりに興味が薄く，ちょっとした手作業でも敬遠してい た学生が自らの手で整備をしたり, 修理をしたりといった 機会が増えてきているように思われる.これらの結果より， 学生のものづくりに対する興味は着実に增加していると考 えられる。

\section{5. 赫}

学生のものづくりへの興味を改善する取り組みとして ものづくりオフィスアワーを実施した. またその概要につ いて紹介した．ものづくりオフィスアワーを通じて, 着害 に学生の意識が変化し，ものづくりに対する興味が徐々に 増加していることが分かった。

この結果より, ものづくり導入教育・ものづくりオフ イスアワーを通して，より多くの学生がものづくりに親し み, 得られた知識・技術を卒業研究や, 卒業後の仕事に発 揮してくれることを望んでいる。 